\title{
Webからの研究者ネットワーク抽出の大規模化 \\ Increasing Scalability of Researcher Network Extraction from the Web
}

\author{
浅田 洋平 \\ 松尾 豊 \\ Yutaka Matsuo \\ 石塚 満 \\ Mitsuru Ishizuka
}

\author{
東京大学大学院 情報理工学系研究科 \\ School of Information Science and Technology, University of Tokyo \\ asadayo@miv.t.u-tokyo.ac.jp \\ 独立行政法人 産業技術総合研究所 \\ National Institute of Advanced Science and Technology \\ y.matsuo@carc.aist.go.jp, http://www.carc.aist.go.jp/ y.matsuo/homepage/top.htm
}

東京大学大学院 情報理工学系研究科

School of Information Science and Technology, University of Tokyo

ishizuka@miv.t.u-tokyo.ac.jp, http://www.miv.t.u-tokyo.ac.jp/ ishizuka/

keywords: web mining, search engine, cooccurrence, social network, scalability

\begin{abstract}
Summary
Social networks, which describe relations among people or organizations as a network, have recently attracted attention. With the help of a social network, we can analyze the structure of a community and thereby promote efficient communications within it. We investigate the problem of extracting a network of researchers from the Web, to assist efficient cooperation among researchers. Our method uses a search engine to get the cooccurences of names of two researchers and calculates the streangth of the relation between them. Then we label the relation by analyzing the Web pages in which these two names cooccur. Research on social network extraction using search engines as ours, is attracting attention in Japan as well as abroad. However, the former approaches issue too many queries to search engines to extract a large-scale network. In this paper, we propose a method to filter superfluous queries and facilitates the extraction of large-scale networks. By this method we are able to extract a network of around 3000-nodes. Our experimental results show that the proposed method reduces the number of queries significantly while preserving the quality of the network as compared to former methods.
\end{abstract}

\section{1.は じめに}

近年，研究に関するさまざまな情報が Web 上に公開 されるようになった . 大学や研究所をはじめとする各研 究機関では, 研究に関する情報を整理し分かりやすく紹 介することに努めており，各種の論文や文献のオンライ ン化 , データベース化も進んでいる .さらに，競争的研 究資金に関する採択課題や現在進行中のプロジェクトに 関する参加者や発表文献の情報なども公開されることが 多くなってきた .

一方で, 研究成果を社会に還元するために，産学官の 連携が重要視されており，研究者がいかに地域や企業と 協力していく体制を作るかは大きな課題である [吉川 02] . また，ロボットやバイオインフォマティクス，ナノテク ノロジーなど, 複数の関連分野か協力して研究を進める 必要のある融合領域, 分野横断研究の必要性も高まって いる．例えば，昨今では，中越地震やインド洋の津波が 大きな被害をもたらしたが, 災害救助に関する研究を実
際に社会に役立てるには，地域住民や行政，企業と研究 者が密接に連携する必要がある。

このような背景から，著者らは，研究者の効果的な協 働関係の構筑のために，研究に関する情報をWeb から 抽出し, 研究者ネットワークおよび研究者に関連する情 報を抽出する研究を行ってきた [松尾 05 , 友部 04 , 安田 04, Mori 04] . 基本的には, Web 上のページにおける名 前の共起関係を検索エンジンを用いて調ベ，テキスト処 理を組み合わせることで，研究者の関係の強さおよび炎 の種類を特定する . 検索エンジンを効果的に使って社会 ネットワークを得ようとする研究は, 国内外でも注目さ れつつあり [Mika 04, 原田 03] , 今後, Web にある大量 の情報を統合することで高次の情報を抽出し，ユーザの 文脈に応じた情報支援を行う方向性は大きな゙潜在的な可 能性を秘めていると考えられる [藤井 04] .

Web 全体を大きなデータベースとみなし情報統合を行 うアプローチは,さまざまな情報が電子化され Web から アクセスできるようになったこと, さらに検索エンジン 
が広く利用可能になったことにより有効性を増している． しかし，一般的なコーパスを用いたテキスト処理と最も 大きく異なる点は, 検索エンジンをいかに効率的に使う かにある . 検索エンジンが広く利用可能になったと言っ ても，イントラの内部に持つ DB のように自由に SQL 文を書けるわけではない . 例えば , Google API では , 1 アカウントあたり 1 日 1000 件の限定のもとに Googleに 検索クエリーを投げることができる*1. 検索エンジンに 対する負荷を下げることは, 今後, 検索エンジンを利用 した情報統合を行う上で避けては通れない重要な課題で ある . 通信ネットワークのレイヤーでは, 帯域を有効に 使うためのパケットの通信方式に関する多くの研究があ るが, より高次の意味処理に近いレイヤーでも，Web 上 のリソースを多くの人が効率的に使えるようにアルゴリ ズムを工夫するという視点が , 今後, 必要性を増してく るであろう．

本論文では, 検索エンジンを用いて, 研究者の協働関 係ネットワークの抽出を行う処理に対して, 大規模化を 可能にするアルゴリズムを提案する . 従来 , Web から 社会ネットワークを抽出する手法は, 大きく 2 つのアプ ローチがあったが, 弚れを融合するひとつの効率的なア ルゴリズムを提案している．弚れにより，従来手法で 500 人程度のネットワークを抽出するのと同等の検索負荷で， 提案手法では 3000 人程度のネットワークを抽出するこ とを可能にしている.

本論文は次のように構成される．2 節では，本研究の もとになった研究者ネットワークの抽出アルゴリズムと 関連研究について述べる . 3 節では, アルゴリズムを提 案し，4節で提案手法を用いて抽出した大規模なネット ワークの具体例を示し，5節で提案手法の評価を行う.6 節で他の研究との関係と本研究の位置づけなどについて 議論し，7 節でまとめを述べる．

\section{2. 関連研究とその問題点}

著者らは, Web における氏名の共起に基づいて研究者 ネットワークを抽出する手法を提案している [松尾 05]. その概要は次の通りである.

（1）研究者の氏名と所属のリストを与える .このリス 卜は, 研究者ネットワークを抽出したいコミュニティ の成員が入ったものである . 例えば , 人工知能の研 究者ネットワークを得たいのであれば, 人工知能学 会の全国大会の著者, 共著者リストなどを用いる .

(2) 各研究者に対して,氏名を検索エンジンのクエリー として検索ヒット数を求める.氏名を $X$ とすると， $X$ を含む Web ページの集合を $D_{X}$, ヒット件数を $\left|D_{X}\right|$ と表すことにする．実際には「氏名 AND 所 属」をクエリとする検索を行うことで，同姓同名の 別人に関する情報を除去している．

*1 http://www.google.com/apis/
(3) 研究者 2 人のペアに対して, 2 つの氏名の Web上 での共起回数を求める.2つの名前を並べて検索エン ジンのクェリーとし（例えば「浅田洋平 松尾豊」）， その検索ヒット数を得る. 氏名を $X, Y$ とすると， $X, Y$ を含む Web ページの集合を $D_{X \cap Y}$ ，ヒット 件数を $\left|D_{X \cap Y}\right|$ とする .

(4) $\left|D_{X}\right|,\left|D_{Y}\right|,\left|D_{X \cap Y}\right|$ から , 2 人の氏名の共起の強 さ $R(X, Y)$ を求める.例えば, overlap 係数 $R(X, Y)$ $=\left|D_{X \cap Y}\right| / \min \left(\left|D_{X}\right|,\left|D_{Y}\right|\right)$ を用いる.ただし， overlap 係数を用いた場合, 単独ヒット件数が極端 に少ない人との関係の強さを正確に測れないという 問題点がある．極端な例として， $\left|D_{X}\right|=1,\left|D_{Y}\right|=$ $100,\left|D_{X \cap Y}\right|=1$ の場合を考えると，1ページしか共 起していないにもかかわらず, overlap 係数は最大の 1 となる .このような現象か問題となるのは, Web上 に情報がほとんどない学生などの研究者 $(X)$ が, 全 国大会の参加者リストなどのページ上で多数の研究 者 $(Y)$ と共起し, 弚れら全ての研究者との overlap 係数が 1 となってしまう場合などである .この問題 を解決するため, [松尾 05] では, 式 (1)のような閾 値付き overlap 係数を用いている.

$$
\begin{aligned}
& R(X, Y)= \\
& \begin{cases}\frac{\left|D_{X \cap Y}\right|}{\min \left(\left|D_{X}\right|,\left|D_{Y}\right|\right)} & \text { if }\left|D_{X}\right|>k \text { and }\left|D_{Y}\right|>k \\
0 & \text { otherwise }\end{cases}
\end{aligned}
$$

閾値付き overlap 係数では, $\left|D_{X}\right|,\left|D_{Y}\right|$ のどちらか が閾値 $k$ ([松尾 05] では 30) 以下の場合には , 光の 二人の関係は誤差のうちとして ,ないものとみなして いる. [松尾 05] では, 共起ページ数, Jaccard 係数, overlap 係数, 閾值付き overlap 係数の炎れ光れを用 いて共起の強さを計算した場合について, 関係の強 さ $R(X, Y)$ を横軸に, 共著関係にある確率を縦軸に とったグラフを描いて評価・考察を行い, 研究者の協 働関係を推定する尺度として閾值付き overlap 係数 が最も適していることを示している．以下，本論文で $\ulcorner$ overlap 係数」と書いた場合には，「閾值 $k=30$ とし た場合の閾値付き overlap 係数」のことを指す．さ らに, [松尾 05] では, 2 人の氏名でヒットした Web ページのテキスト解析を行うことで, 共著, 同研究 室 , 同プロジェクト, 同発表などの関係の種類を特 定している.

Mika らは ,この手法とほぼ同じ手法を提案している [Mika 04] . 共起の強さを計るために Jaccard 係数 $R(X, Y)$ $=\left|D_{X \cap Y}\right| /\left|D_{X \cup Y}\right|$ (ただし , $\left|D_{X \cup Y}\right|$ は $X, Y$ のいずれ かを含む Web ページ数) を用いている点, テキスト解 析による関係の種類の判別を行っていないなどの点で異 なるが , 基本的には同じアルゴリズムである . 検索エン ジンにより 2 つの語の間の関係性の強さを求める方法 
は，最近では比較的知られてきており，例えば Google Hacks[Calishain 03] の中で紹介されている .これらは， あらかじめ名前を与えたときに，弚の関連の強さを計る 方法を基本としている。

これらの研究の起源となったのは, Kautz らの Referral Web の研究である [Kautz 97] . Referral Webでは, まず システムに入力した名前をクェリーとして検索し，弚の検 索結果のページから人名を抽出し，関係の強さを Jaccard 係数で計算し，さらに关れらの人名をクェリーとして検 索することを繰り返す，乥れにより，最初の名前を中心 とした人のネットワークが抽出されることになる．また， 原田らは, 研究トピックや分野を表す検索語を入力とし， 検索にヒットした最大 1000 件の Web 文書から人名を抽 出し, 弚の共起関係を調へている [原田 03] . [原田 03] で は，検索語に関連する人物の関係を可視化することが目 的であるため，人物の関係を調べる際にWeb 全体を対 象とせず，検索語に関連する最大 1000 件の文書におけ る共起のみを調べている .これらは, Web の検索結果の (上位) ページから名前を抽出した上で, 氏名の関係の強 さを計算する方法である．

ここで, 松尾らやMika ら, 前者の手法の問題となるの が, 必然的にノード数 $n$ に対して, $O\left(n^{2}\right)$ の検索クエリー を検索エンジンに投げる必要がある点である . Referral Web では，この点が問題となり，最初に与えた氏名から 数ノード以上のネットワークを抽出することは , ノード 数が爆発してしまい，実質不可能である．原田らの方法 は，あらかじめ対象とする Web 文書に 1000 件という上 限を設定することで，この問題を回避している.

対象となる文書を限定することは，検索エンジンの負 荷を下げることはできるが , 関係が強いことを示す Web ページか㳔象文書以外に存在する可能性がある . 例えば， 学生同士が一緒に書いた授業のレポートを載せた Web ページは, 光の学生同士の関係性を示す証拠ではあるが， 検索結果の上位に現れない可能性もある．一般的には検 索エンジンの負荷を下げることと，抽出すべき関係を取 り逃がさないことはトレードオフの関係にあり，なるべ く検索エンジンの負荷を減らしながら取り逃がす関係を 少なくする手法か望ましい。

\section{3. 提 案 手 法}

本節では，Web 上の情報を用いて研究者ネットワーク を抽出する際，検索エンジンの負荷と検索精度のトレー ドオフを解消する新しい手法を提案する .

\section{$3 \cdot 1$ 提案手法の考え方}

松尾らや Mika らの従来手法では, 与えた氏名のリス 卜中の全ての組み合わせに対して，検索エンジンにクェ リーを投げ，氏名が共起するWeb ページの数を調べる． しかし，容易に想像がくように，得られる関係性のネッ

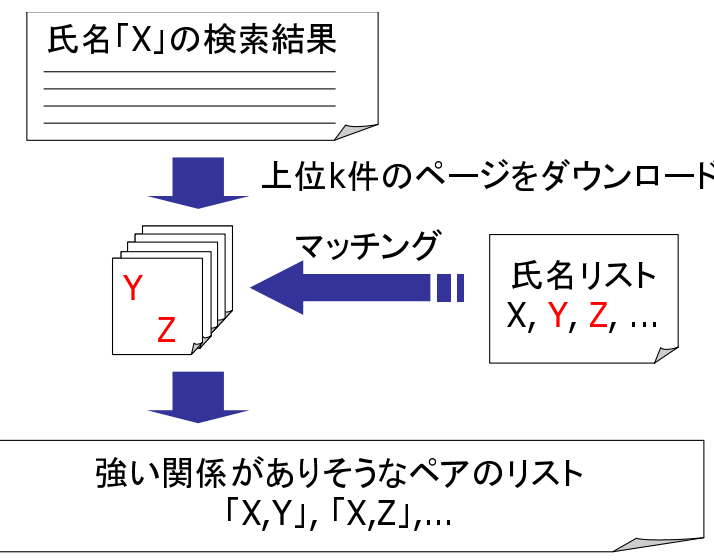

図 1 提案手法

トワークは非常にスパースである . 例えば，人工知能学 会の 266 人のネットワークではエッジ数が 690 であり [松 尾 05], ネットワークの密度 (存在するエッジ数を可能 なエッジ数で割ったもの) は 0.0195 と小さい．つまり， 任意の 2 人のうち $2 \%$ 程度の間にしか強い関係は存在し ておらず，すべての 2 人の組み合わせについて検索エン ジンを利用するのは効率が悪い .

ひとつの方法として，関係が強い人を共有する(つま り共通の知人を持つ） 2 者間にだけ，関係が存在するか どうかを検索エンジンを用いて調べるアプローチが考え られる .つまり，存在するエッジは強い紐帯 [安田 97] で あると仮定し，ネットワークを徐々に広げていく方法で ある.しかし，人の関係で面白いのは，意外な人のつな がりであり，すでに分かっている関係から存在するであ ろう関係を予測する方法は, ネットワークを把握する上 で重要な「弱い紐帯」を取り逃がすことになる [安田 97] .

乥こで，本手法では次のようなアプローチを取る．あ る人を考えたときに光の人と関係が強い人は, 兴の人の 氏名で検索した上位の文書にお光らく含まれているだろ うと考えることができる，例えば，浅田洋平」という氏 名で検索したとき，光の上位には，浅田洋平の所属する 研究室のメンバーリストや発表文献, 学会プログラムな どが含まれるが, 浅田洋平と強い関係にある指導教員や 共著者といった氏名は上位文書の中に含まれる．もちろ ん, 偶然に同じ研究会で発表した人の氏名など, 強い関 係にない名前も含まれることになるが，少なくとも，強 い関係にある人を取り逃がすことは少ないので, フィル タリングとして用いることができると考えられる .

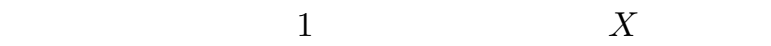
リとして検索された上位 $k$ 件のページを取得し，氏名リ スト中の氏名が含まれていないかを調べる．本手法では， 氏名リストは与えられているので, 氏名をパターンとす る文字列マッチングを行うだけでよい.ただし，テキスト 中では姓と名が半角スペースや全角スペース, タブなど で区切られていることがあるので，あらかじめテキスト から半角スペース, 全角スペース, タブなどを除去した 
表 1 情報系研究者ネットワークのノードと抽出に必要なクエリ数

\begin{tabular}{c|c}
\hline \hline ノード & $\begin{array}{l}\text { ReaD 研究開発支援ディレクトリの } \\
\text { 「情報工学」「複合領域 - 情報科学」 } \\
\text { の研究者 }\end{array}$ \\
\hline ノード数 & 2879 \\
\hline 従来手法によるクエリ数 & 4142881 \\
\hline 提案手法によるクエリ数 & 137967 \\
\hline \hline
\end{tabular}

上で処理を行う．光して，この上位 $k$ 件のページに含ま れる氏名 $(\ulcorner Y\lrcorner\ulcorner Z\lrcorner)$ との間には強い関係があり光うで あると推測し，これらの氏名との共起 $(\ulcorner X, Y\lrcorner\ulcorner X, Z\lrcorner)$ のみを検索エンジンで調へることにする.これにより，強 い関係を取りこぼすことなく，検索エンジンに対する負 荷を減らすことができると考えられる。

\section{$3 \cdot 2$ 提案手法の流れ}

提案手法は，次のようなステップを踏む．

Step1 ネットワークを構成するメンバーの氏名と所属 のリストを用意する .

Step2 氏名リスト中の全ての氏名「X」をクエリとし， Web 検索を行い，兴の氏名を含む Web ページ数 $\left|D_{X}\right|$ を調べる.本研究では，[松尾 05]にならい， 同姓同名の別人を除去するために「氏名 AND 所属」 で検索した .このとき，検索結果における上位 $k$ 件 のページを解析し，氏名リスト中の氏名 $\ulcorner Y\lrcorner$ があ れば，弚のペア $X, Y$ は共起ページ数を検索するぺ アのリストに追加する .

Step3 共起ページ数を検索するペアのリスト中の全て のペア $X, Y$ について,$X$ AND $Y\lrcorner$ をエリとして Web 検索を行い, 二人の氏名が共起する Webぺー ジ数 $\left|D_{X \cap Y}\right|$ を調べる.検索していないペアについ ては, $\left|D_{X \cap Y}\right|=0$ とする.

Step4 リスト中の全ての氏名のペア $X, Y$ につて, 光 れらの関係の強さ $R(X, Y)$ を overlap 係数 $R(X, Y)=$ $\left|D_{X \cap Y}\right| / \min \left(\left|D_{X}\right|,\left|D_{Y}\right|\right)$ で計算する.

\section{4. 大規模ネットワークの抽出}

提案手法を用いて，実際に 3000 人規模のネットワー クを抽出した . 情報系の研究者を対象とし, 表 1 に示す ネットワークを抽出した ${ }^{* 2}$.

抽出された大規模ネットワークの一部を図 2 に示す. ネットワークの表示には, Graphviz ${ }^{* 3}$ 用い, ばねモ デルにより，ノード間の距離が overlap 係数の逆数を反 映するようなレイアウトを求めている．図 2 では，955 のノードと，1936 本のエッジを表示している．ただし， 2879 人全ての関係を抽出しているが , ネットワークを表 示する際には, まず overlap 係数が 0.5 以上のエッジを

$* 22004$ 年 2 月時点での Google による結果 .

$* 3$ http://www.research.att.com/sw/tools/graphviz/
実線で表示し, エッジ数が 3 本以下のノードについては, overlap 係数が 0.3 から 0.5 のエッジも破線で表示して いる.この結果，孤立ノードになってしまった研究者は 表示していない.多くの研究者と協働関係にある研究者 の周りにはエッジが集中しており，黑くなっているのが 分かるが, ネットワークの密度は 0.004 であり，任意の 二人のうち, $0.4 \%$ 程度の間にしか強い関係はないことが 分かる.ネットワークを抽出する際に要したクエリ数は 表 1 の通りである. 従来手法に対し, 提案手法では, 約 97\%のクエリを削減できている.従来手法では，4142881 個のクエリが必要となるので, このネットワークを抽出 することは困難である .

\section{5. 評 価 実 験}

\section{$5 \cdot 1$ 実 験 方 法}

提案手法は, 氏名単独の検索結果の上位 20 件のペー ジ中で共起している氏名とのペアについてのみ, 強い関 係があり光うなペアであるとして，検索エンジンに対す る負荷を減ら弚うとするものである．すなわち，従来手 法では全ての関係をもれなく抽出できるが，提案手法で は共起ページ数を検索するペアのフィルタリングを行っ ているので, 関係を取りこぼす可能性がある．したがつ て，提案手法を用いることで，従来手法に対して，

・どれだけ検索エンジンに対する負荷が減ったか

・どの程度の関係を抽出できているのか

の 2 点に対して評価を行う.

前者の点については, 共起ページ数の検索に要したク エリ数によって評価できる.

後者の点については, 提案手法は, 上位 20 件のペー ジに出現する氏名との共起ぺージ数しか調べていないの で，弱い関係を抽出することを犠牲にしている，弚こで， overlap 係数に閾值を設け, 閾値以下の関係をないもの とみなした場合に，何\%の関係を抽出できたかを測る指 標として，式 (2)のように被覆率を定義した .

$$
\text { 被覆率 }=\frac{\text { 提案手法による閾値以上の関係の数 }}{\text { 従来手法による閾値以上の関係の数 }}
$$

閾值を変えて被覆率を調べることで, 提案手法がどの程 度の関係を何\%抽出できたのかということを評価できる．

本評価実験では，500人程度の規模のネットワークを 従来手法, 提案手法の二つの方法で抽出し, 結果を比較 した . 検索エンジンとしては代表的な検索エンジンの一 つである Google を用いた . 実験で抽出したネットワー クのノードを表 2 に示す. 提案手法では， $k=20$ ，すな わち, 氏名単独の検索結果の上位 20 件のページに出現 する氏名との共起ページ数についてのみ検索を行った .

また, 本評価実験では, overlap 係数を計算する際に， 閾值付き overlap 係数を用いたため, 従来手法, 提案手 法のいずれの場合も, ヒット件数が 30 件以下の研究者と の関係については抽出していない . 閾値付き overlap 係 


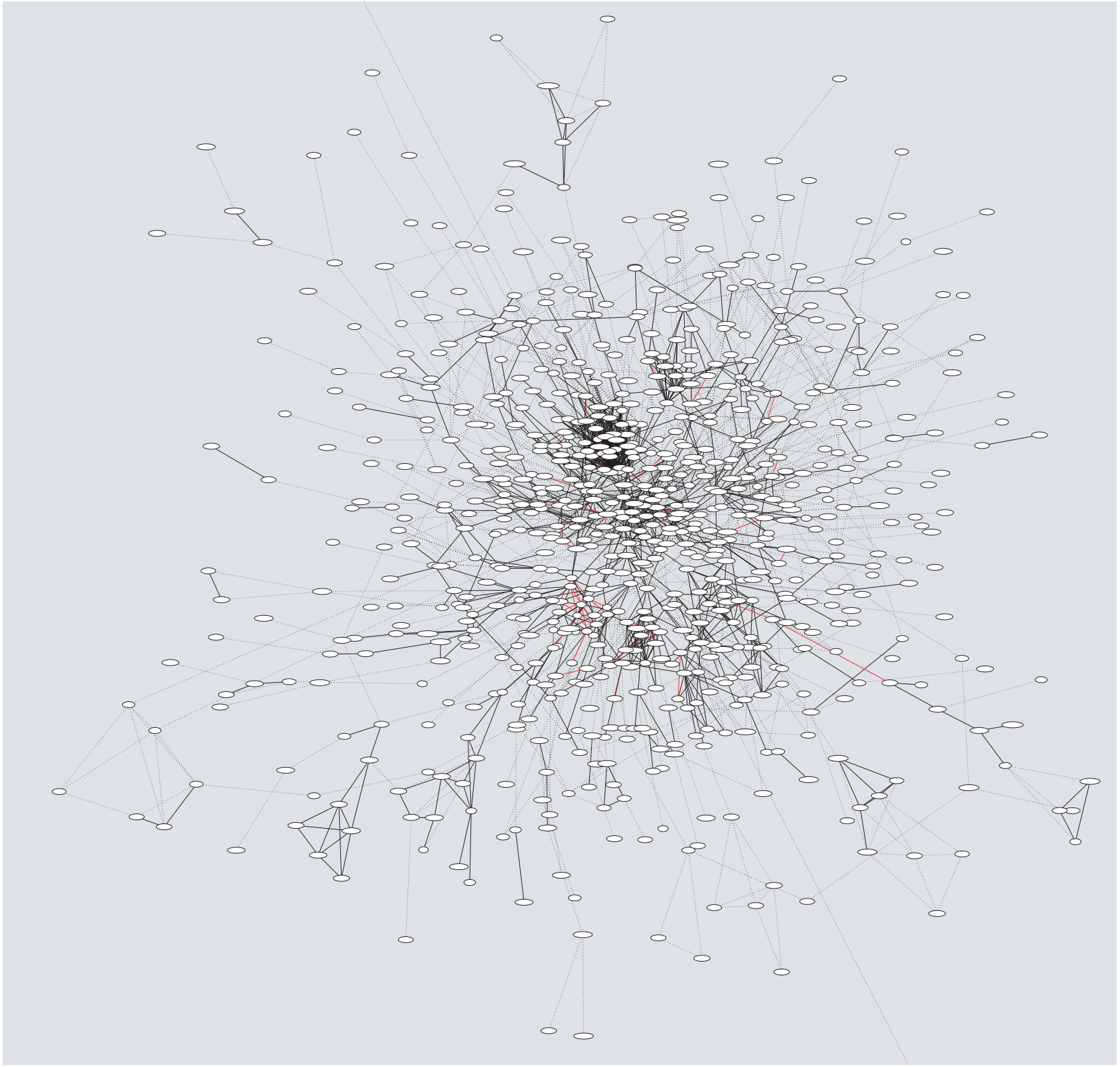

図 2 情報系研究者のネットワーク (一部)

表 2 実験で抽出したネットワークのノードとネットワーク抽出に 要したクエリ数

\begin{tabular}{c|c}
\hline \hline ノード & JSAI2003 の参加者 \\
\hline ノード数 & 503 \\
\hline 従来手法によるクエリ数 & 126253 \\
\hline 提案手法によるクエリ数 & 19182 \\
\hline \hline
\end{tabular}

数と，これを用いる理由については，2 節 $(4)$ を参照さ れたい.

\section{$5 \cdot 2$ 結 果}

\section{$\S 1$ 提案手法 ( $k=20)$ の評価}

まず，従来手法と提案手法の弚れ帒れの手法を用いた 場合に検索エンジンに与えたクエリの数は表 2 に示す通 りである．表 2 から，提案手法を用いることで , 検索エ ンジンに与えるクェリの数が約 $85 \%$ 減っているというこ
とが分かる．このことから，提案手法を用いることで検 索エンジンに対する負荷が大幅に減っていることが分か る.また，表 1 と表 2 を比べると，従来手法で 500 人程 度のネットワークを抽出するのと同等のクエリ数で, 提 案手法では 3000 人程度のネットワークを抽出できるこ とが分かる.

次に，提案手法により抽出できた関係の強さの傾向を 調べる目的で，全ての関係について提案手法と従来手法 の光れよって overlap 係数を求め，横軸を従来手 法による overlap 係数，縦軸を提案手法による overlap 係数とするグラフ上にプロットした . 結果を図 3 に示す . プロットされた点は, 任意の二人の研究者の関係を意味し ている . 図 3 では, 理想的には全ての関係は $(0,0),(1,1)$ を結ぶ直線上に並ぶはずであり，横軸上のドットが，提 案手法によって抽出できなかった関係を示している．図 


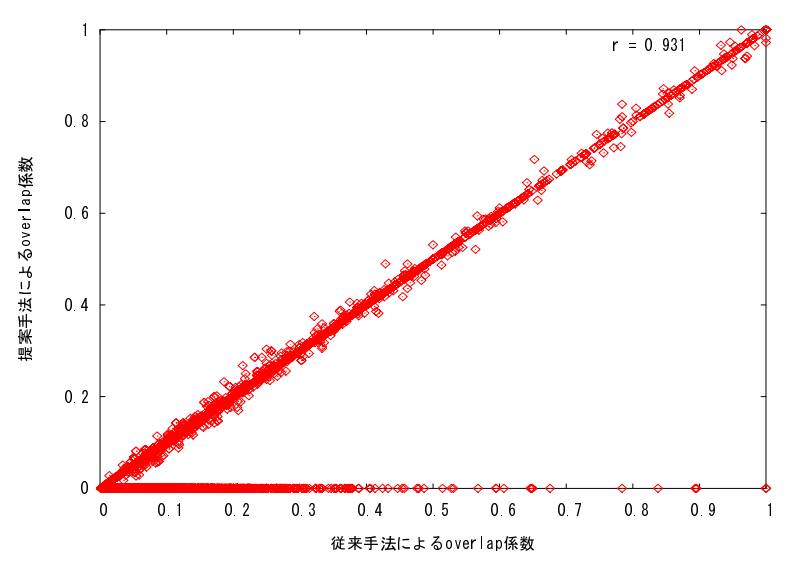

図 3 従来手法と提案手法の相関

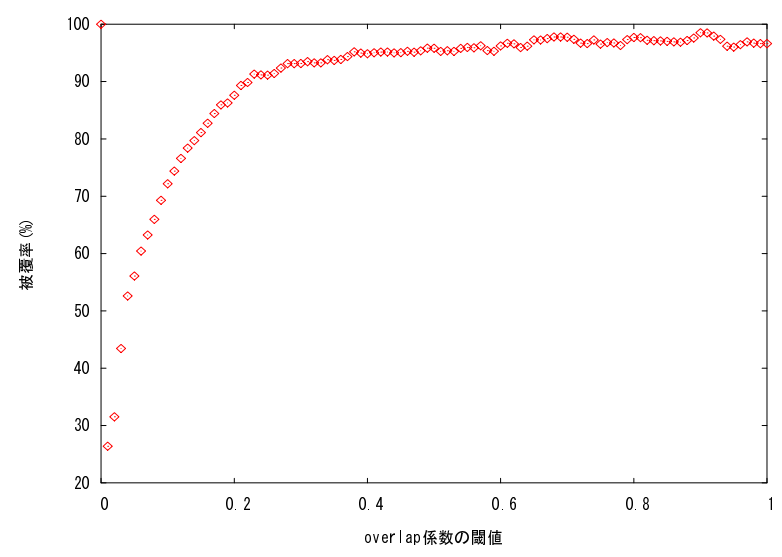

図 4 閾値による被覆率の変化

中で, 従来手法, 提案手法ともに抽出された関係であつ ても正確には $(0,0),(1,1)$ を結ぶ直線上にないものがあ るのは , 検索エンジンのデータベースが日々更新されて いることによるものである. 傾向として, overlap 係数 が大きくなるにしたがって，すなわち強い関係ほど，提 案手法での取りこぼしが少ないことが分かる．ピアソン の積率相関係数を求めると, $r=0.931$ であった .

また, overlap 係数の閾值を 0 から 1 まで 0.01 刻みに 変化させた場合の被覆率を式 $(2)$ によって求めた . 結果を 图 4 に示す. 図 4 から, overlap 係数が 0.2 以上の関係に ついては約 88\% , 0.3 以上の関係については, 約 $93 \%$ 抽出できていることが分かる. [松尾 05] では, 人間関係 ネットワークを表示する際に, まず overlap 係数が 0.7 以上のエッジを表示し, 総エッジ数が 3 本以下のノード については overlap 係数が 0.5 から 0.7 までのエッジも 表示するようにしている. 対象とするコミュニティの規 模や種類によって，表示に適切な overlap 係数の閾值は 異なると考えられるが，例えば，提案手法で 0.2 以上の エッジを全て表示した場合，従来手法の約 $88 \%$ のエッジ を表示できることになる．

以上をまとめると，提案手法を用いると，従来手法に 比べて

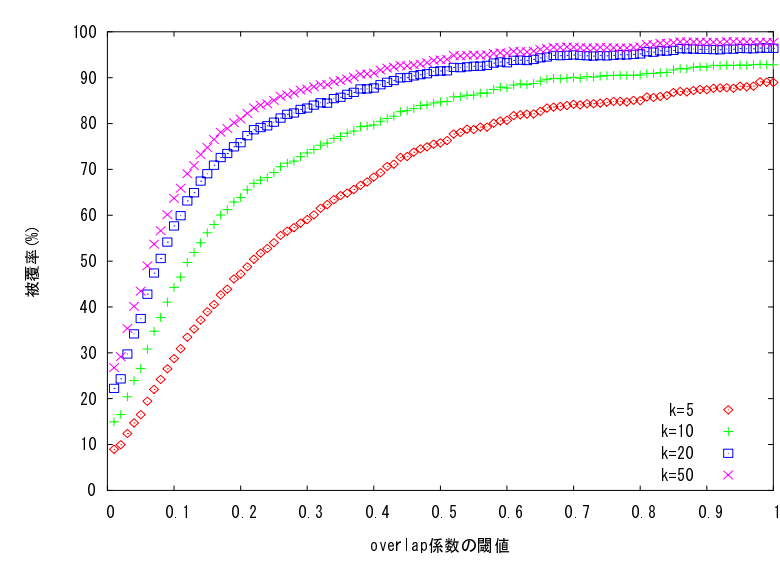

図 $5 \quad k$ を変化させたときの被覆率の変化

・検索エンジンに対する負荷が $85 \%$ 減少し，

- overlap 係数 0.2 以上の関係については約 $88 \%$ 抽出 できる

という評価ができる，すなわち，提案手法は，強い関係 の取りこぼしを最小限に抑えつつ，検索エンジンに対す る負荷を大幅に減少できていることが分かる．

$\S 2$ パラメータに関する評価

$k$ の値を変化させたときに被覆率がどのように変化す るかを調べた .この実験では, 検索エンジンのデータベー ス更新により共起ページ数が変化し, 抽出された関係の overlap 係数が手法によって異なってしまう問題を避け るため, 提案手法の overlap 係数は, 共起ページ数を検 索したペアについては従来手法と同じ値，弚れ以外の場 合には 0 とした . $k=5,10,20,50$ の 4 通りについて被 覆率のグラフを描くと，图 5 のようになった . $k$ を大き くするほど被覆率か改善されている，すなわち，多くの ページを解析するほど多くの関係を抽出できていること が分かる. また,$k=5$ と $k=10, k=10$ と $k=20$ の 系列の差に比へて , $k=20$ と $k=50$ の系列の差は小さ くなっている．このことは，強い関係にある人の氏名が 検索結果上位のページに多く出現し，ある程度以上に $k$ を大きくしても被覆率の改善は小さいことを示している と考えられる.$k$ を大きくすると，上位 $k$ ページ中でよ り多くの氏名と共起することになり，氏名の共起ぺージ 数を検索するのに必要なクエリ数も多くなるので, 抽出 するネットワークの種類や規模に応じて $k$ の值を決めれ ばよいことが分かる .

次に, ネットワークのノード数 $n$ に対する, 共起ペー ジ数の検索に要するクエリ数のオーダについて理論的に 考察する.

氏名単独をクエリとして検索された上位 $k$ 件の Web ページ中で共起している氏名リスト中の氏名の数が一人 当たり平均 $m$ 人 $(m \leq n)$ であるとする.共起ページ数 の検索に要するクエリ数は, 高々 $n \times m$ である .

ノード数 $n$ の増加にしたがって , 共起氏名数 $m$ も増加 するので, 明らかに $m$ は $n$ の関数である.$m$ の関数を推 
定することは難しいが， $k=20$ とした場合，JSAI2003 参加者のネットワークでは $m=\frac{19182}{503} \approx 38$, 情報系研究 者のネットワークでは $m=\frac{137967}{2879} \approx 48$ である. この例 を見る限り， $n$ の増えかた (5.7 倍) に対して $m$ の増え 方 (1.3 倍) は緩やかであるし，一つの氏名と共起しう る氏名の数には上限があるため, 提案手法によるクエリ 数は $n \geq 3000$ のネットワークの抽出に対しても，ほぼ $O(n)$ の増加に抑えられると考えられる .

\section{6. 議 論}

$$
\text { ソーシャルネットワークの抽出について，これまで樣々 }
$$
な研究が行われてきた .

Web を情報源としてソーシャルネットワークを自動 的に抽出する研究としては, 松尾らの研究 [松尾 05 , 友 部 04] の他にも，Referral Web [Kautz 97] や，Mika らの研究 [Mika 04], 原田らの研究 [原田 03], SocialPathFinder [Ogata 99]などがある.本節では，光れら の関係をまとめ関連付けるために,やや詳しく各研究を 紹介する .

Referral Web [Kautz 97] は ,ソーシャルネットワー クを用いた情報検索，エキスパート検索システムである . ユーザがシステムに氏名を登録すると，システムは検索 エンジン*4を用いて产の氏名を含む Web ページを検索 する . 次に ，検索されたWeb 文書から固有表現抽出によ り，氏名を抽出し，氏名リストを作成する，光して，ユー ザが入つた氏名 $「 X\lrcorner$ ，氏名リスト中の氏名 $\ulcorner Y\lrcorner の$ 全てのペアについて $\ulcorner X$ AND $Y\lrcorner,\ulcorner X$ OR $Y\lrcorner$ をエ リとした Web 検索を行い，検索されたぺージ数を乥れ

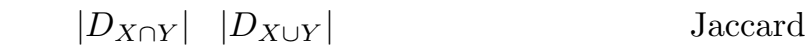
係数 $\left(\frac{\left|D_{X \cap Y}\right|}{\left|D_{X \cup Y}\right|}\right)$ て計算する .さらに氏名リスト中の氏名 をシステムに入力する，ということを $i$ 回繰り返すこと で , ユーザを中心とする半径 $i$ のネットワークを得ること ができる．このネットワークを蓄積していくことで，大 規模なネットワークを抽出する．しかし，この手法では， あらかじめ氏名リストを用意せず，固有表現抽出により 氏名リストを抽出するため，例えば情報系の研究者ネッ トワークを抽出したい場合にも，情報系ではない研究者 および，研究者でない人もネットワークに含まれてしま うことになる．また，全体のネットワークは，各ユーザ の半径 $i$ のネットワークを統合したもので , 氏名をクエ リとした検索を行っていないノードについては，重要な 関係を取りこぼしている可能性があり，網羅的ではない． 検索回数については, 一つの氏名と共起する全ての氏名 の数が平均 $x$ であると仮定すると, ノード数 $n$ のネット ワークを抽出するためには高々 $n \times x$ の検索クエリが必 要となる.$x$ は非常に大きな数になると考えられるが $n$ に依存しない定数であるため, 検索回数は提案手法と同 じ $O(n)$ である .ところで, $x$ が一つの氏名と共起する

*4 AltaVista(http://www.altavista.com/) を用いている.
全ての氏名の数であるのに対して， $m$ は光のうち上位 $k$ 件のページ中で共起する，氏名リストに含まれる氏名の 数であるから, 明らかに $x>m$ である.すなわち, 提案 手法の検索回数は 5.2 節で述べたとおり高々 $n \times m$ であ るから, ReferralWeb の検索回数 $n \times x$ は提案手法より も多い.

Mika らは, 従来手法とほぼ同樣の手法を提案してい る [Mika 04]．すなわち，あらかじめ氏名リストを用意 し，検索エンジンで氏名の共起ページ数を調べる. 共起 の強さには Jaccard 係数を用いている点, 関係にラベル をつけていない点が松尾らの手法と異なるが, 基本的な アルゴリズムは同樣である．したがって，従来手法と同 樣，ネットワークのノード数 $n$ に対して ${ }_{n} C_{2}$ の検索クエ リが必要となり, 大規模なネットワークの抽出が困難で あるという問題がある。

原田らは，あるトピックに関するキーパーソンの関係 を抽出するシステムを提案している [原田 03] . ユーザが トピックを入力すると, システムは検索エンジンで光の トピックをクエリとする Web 検索を行い，最大で上位 1000 件の Web ページを取得する . 次に , これらのペー ジから固有表現抽出によって人名を抽出し，兰れぞれの 人名について，検索結果の Web ページの集合と光の人 名を含む全ての Web ページの集合の重なり度合いを対 数尤度比検定で用いられる G スコア [Dunning 93] で計 算し，これを关の人名とトピックの関連度とする．さら に，Web ページ中での共起の距離に基づいて人名間の関 係の強さを計算し，トピックに関連する人間の関係を抽 出している．この手法では, 人名間の関係の強さを計算 する際に検索エンジンを用いないため, クエリ数につい ては問題がない．しかし，対象とする情報源をトピック に関連する最大 1000 件の Web ページに限定しているの で,重要な人物や重要な関係を取りこぼす可能性がある． すなわち，ノード間の関係は網羅的ではない .

SocialPathFinder [Ogata 99] は, ユーザの Web ペー ジに存在するハイパーリンクによって人間関係を抽出す るシステムである . システムはユーザのホームページを 起点として , ハイパーリンクをたどり，リンク先のペー ジが個人のホームページであるかどうかを URL やメー ルアドレスの情報から推定する . 個人のホームページに おけるリンク関係を用いることで, プライベートな関係 を抽出することができるが，ホームページを持っていな い人との関係は抽出できない，また，個人の名前はURL やメールアドレスから抽出するので,「ogata」「okawa」 といった本人以外には分かりにくいものであるだけでな く，弚も光も URLやメールアドレスが個人名になって いない場合には関係を抽出できない，すなわち，重要な 人物，関係を取りこぼす可能性があり，ノード間の関係 は網羅的ではない．

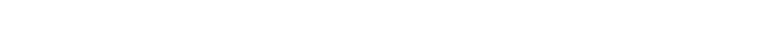
相違を表にまとめると，表 3 のようになる.表 3 から，関 
表 3 Web を用いたソーシャルネットワーク抽出手法の比較

\begin{tabular}{|c||c|c|c|c|c|c|}
\hline & 松尾らの手法 & Referral Web & Mika らの手法 & 原田らの手法 & SocialPathFinder & 提案手法 \\
\hline \hline 関係の根拠 & 氏名の共起 & 氏名の共起 & 氏名の共起 & 氏名の共起 & ハイパーリンク & 氏名の共起 \\
\hline 関係の強さ & overlap 係数 & Jaccard 係数 & Jaccard 係数 & 共起距離 & なし & overlap 係数 \\
\hline 氏名リスト & あらかじめ用意 & 固有表現抽出 & あらかじめ用意 & 固有表現抽出 & URL, E-mail アドレスから抽出 & あらかじめ用意 \\
\hline 情報源 & Web 全体 & Web 全体 & Web 全体 & 最大 1000 ページ & 個人の Web ページ & Web 全体 \\
\hline 検索エンジンへの負荷 & $O\left(n^{2}\right)$ & $O(n)$ & $O\left(n^{2}\right)$ & 1 & なし & $O(n)$ \\
\hline 関係の網羅性 & $\bigcirc$ & $\times$ & $O$ & $\times$ & $\times$ & $\bigcirc$ \\
\hline
\end{tabular}

係の網羅性が低いと，検索エンジンの負荷が小さくなる ことが分かる.すなわち , ネットワークを取りこばしな 〈網羅的に抽出することと，検索エンジンに対する負荷 を減らすことは一般的にトレードオフの関係にあり，従 来の研究は,

・情報源を絞りこむことで関係の網羅性を犠牲にするも の: 原田らの手法, SocialPathFinder , ReferralWeb (情報源は Web 全体としているが, 重要な関係を取 りこぼす可能性があるため，こちらに分類した）

・関係の網羅性を優先することでクエリ数が多くなる もの: 松尾らの手法, Mika らの手法

の二つに分けられることになる .

本論文の提案手法は, 情報源は Web 全体としながら も，検索エンジンに投げるクェリに対してフィルタリン グを行うことで, 網羅性を保ちつつ検索エンジンへの負 を減らすシンプルかつ有効なアプローチであると考えら れる。

また, ソーシャルネットワーク抽出以外の分野でも， Web マイニングの研究では, 検索エンジンを用いて語の 共起を調べる研究が行われている. 例えば，Tuneyは， 語と語の意味的な関係の強さをWeb 上での共起にもと づいて推定する手法を提案している [Tuney 03] . しかし， Tuney 自身が言及しているように，この場合もソーシャ ルネットワークの抽出と同樣に検索エンジンへのクエリ の数か問題となっている

このように，Webから検索エンジンを用いて関係を抽 出する手法は有効なものであるが, 潜在的にクエリ数の 問題が存在しており, 今後, Web マイニングの分野にお いて, 本論文の提案手法のようなアプローチの必要性が 高まると考えられる .

\section{7. おわりに}

Web 上の情報からの研究者ネットワークの抽出手法 の従来手法において，検索エンジンに与えるクエリをフ イルタリングすることでクェリの数を減らし, 大規模な ネットワークの抽出を可能にする手法を提案した .また， JSAI2003 の参加者を例にとって従来手法と提案手法を 用いてネットワークを抽出し評価を行い, 提案手法によ り，強い関係の取りこぼしを最小限に抑えつつ，検索エ ンジンに対する負荷を従来手法に対して大幅に削減でき
ることを示した . 本論文では研究者を対象としてWeb 上 での共起を調へているが，提案手法は，Webにおける名 前の共起を調べる際に，広い適用範囲に対して有効な可 能性があると考えている .

\section{謝辞}

本研究を行う上でお世話になった全ての方に心より感 謝いたします．

\section{$\diamond$ 参 考 文 献 $\diamond$}

[Calishain 03] Calishain, T. and Dornfest, R.: Google Hacks, O'reilly (2003)

[Dunning 93] Dunning, T. E.: Accurate methods for the statistics of surprise and coincidence, Computational Linguistics, Vol. 19, No. 1, pp. 61-74 (1993)

[藤井 04] 藤井 敦 : 百科事典としての WWW, 人工知能学会誌, Vol. 19, No. 3, pp. 296-301 (2004)

[原田 03] 原田 昌紀, 佐藤 進也, 風間 一洋: Web 上のキーパーソン の発見と関係の可視化, 情報処理学会研究報告 DBS-130/FI-71 (2003)

[Kautz 97] Kautz, H., Selman, B., and Shah, M.: The hidden web, AI Magazine, Vol. 18, No. 2, pp. 27-36 (1997)

[松尾 05] 松尾 豊, 友部 博教, 橋田 浩一, 中島 秀之, 石塚 満 : Web 上の情報からの人間関係ネットワークの抽出, 人工知能学 会論文誌, Vol. 20, No. 1, pp. 46-56 (2005)

[Mika 04] Mika, P.: Bootstrapping the FOAF-Web: an experiment in social network mining, in Proc. 1st Workshop on Friend of a Friend, Social Networking and the Semantic Web (http://www.w3.org/2001/sw/Europe/events/foafgalway/papers/fp/bootstrapping_the_foaf_web/) (2004)

[Mori 04] Mori, J., Matsuo, Y., Ishizuka, M., and Faltings, B.: Keyword extraction from the Web for person metadata, in Poster Abstracts 3rd Int'l Semantic Web Conference(ISWC2004), pp. 45-46 (2004)

[Ogata 99] Ogata, H., Fukui, T., and Yano, Y.: SocialPathFinder: computer supported exploration of social networks on WWW, in ICCE99, vol.2, pp. 768-771 (1999)

[友部 04] 友部 博教 : 知識共有システムにおける知識の獲得・加 工・管理に関する研究, PhD thesis, 東京大学大学院情報理工学 系研究科 (2004)

[Tuney 03] Tuney, P. D.: Coherent keyphrase extraction via web mining, in Proc. of the 18th Intl. Conf. on Artificial Intelligence(IJCAI-03), pp. 434-439 (2003)

[安田 97] 安田 雪: 社会ネットワーク分析 - 何が行為を決定する か-, 新曜社 (1997)

[安田 04] 安田 雪: 人脈づくりの科学, 日本経済新聞社 (2004)

[吉川 02] 吉川 弘之 : 科学者の新しい役割, 岩波書店 (2002)

〔担当委員 : 黄瀬 浩一〕

2005 年 2 月 23 日 受理 


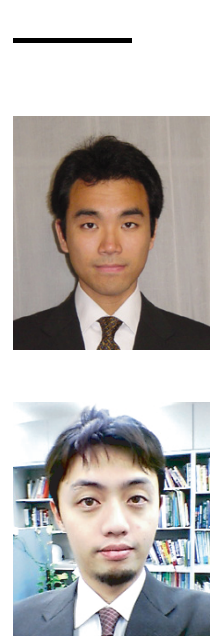

\section{者 紹}

\section{浅田 洋平}

2003 年東京大学工学部電子情報工学科卒業. 2005 年同 大学院情報理工学系研究科修士課程修了. 同年 4 月より, 松下電器産業株式会社パナソニックオートモーティブシス テムズ社勤務 . カーエレクトロニクスと Web マイニング の融合により，より快適なカーライフを実現することに興 味がある。

\section{松尾 豊(正会員)}

1997 年東京大学工学部電子情報工学科卒業. 2002 年同 大学院博士課程修了. 博士 (工学). 同年より, 産業技術 総合研究所サイバーアシスト研究センター勤務 . 2004 年 より産業技術総合研究所情報技術研究部門勤務. GBRC 社会ネットワーク研究所研究員.(株) ホットリンク技術 顧問. 2003 年度人工知能学会論文賞受賞. 高次 Web マ イニングに興味がある.情報処理学会, AAAI 各会員 .

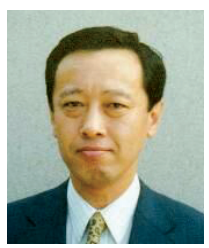

\section{石塚 満(正会員)}

1971 年東京大学工学部電子卒, 1976 年同大学院博士修 了. 同年 NTT 入社, 横須賀研究所勤務. 1978 年東大大 学生産技術研究所・助教授, (1980-81 年 Purdue 大学 客員準教授)，1992 年東京大学工工学部電子情報·教授, 2001 年情報理工学系研究科・電子情報学専攻, 2005 年同 創造情報学専攻 (電子情報学専攻兼任). 研究分野は人工知 能, Web インテリジェンス, 次世代 Web 情報基盤, 生 命的エージェントによるマルチモーダルメディア.IEEE, AAAI, 情報処理学会, 電子情報通信学会, 映像情報メディア学会, 画像電子学 会 , 等の会員 . 